\title{
Use of an elevated avenue for leisure-time physical activity by adults from São Paulo downtown, Brazil
}

\author{
Eduardo Quieroti Rodrigues, ${ }^{1,2,}$, Leandro Martin Totaro Garciaa, ${ }^{2,3}$, Evelyn Helena Corgosinho Ribeiro', Ligia Vizeu \\ Barrozo $^{4}$, Regina Tomie Ivata Bernal ${ }^{5}$, Douglas Roque Andrade ${ }^{2}$, João Paulo dos Anjos Souza Barbosa ${ }^{1,2}$, Ana Paula \\ de Oliveira Barbosa Nunes ${ }^{2}$, Rogério César Fermino ${ }^{6,7}$ and Alex Antonio Florindo ${ }^{1,2}$
}

1 Graduate Program in Nutrition in Public Health, Department of Nutrition, School of Public Health, University of São Paulo, São Paulo City 01246-904, Brazil;

2. School of Arts, Sciences and Humanities, University of São Paulo. Physical Activity Epidemiology Group. São Paulo City 03828-000, Brazil;

3. Centre for Public Health, Queen's University Belfast, Belfast, UK;

4. Department of Geography, School of Philosophy, Literature and Human Sciences, University of São Paulo, São Paulo City 05508-080, Brazil;

5. University of Minas Gerais State. School of Nursing. Belo Horizonte, Minas Gerais, Brazil;

6. Graduate Program in Physical Education, Research Group on Environment, Physical Activity, and Health, Federal University of Technology - Paraná, Curitiba, Paraná, Brazil;

7. Graduate Program in Physical Education, Federal University of Paraná, Curitiba, Paraná, Brazil;

* Correspondence: eduquieroti@gmail.com, Phone: +55 11 3091-8157

\begin{abstract}
Leisure-time physical activity (LTPA) is associated with access and use of public open spaces. The "President João Goulart Elevated Avenue" and current denominated "Minhocão" is a facility for leisure activities that are open for people during the night/weekends. The aim of this study was to examine if the prevalence of LTPA among individuals living in the surroundings of Minhocão is different according to proximity to, and use of, the facility. We conducted a cross-sectional study with cluster sampling with people aged $\geq 18$ years who lived in households until $500 \mathrm{~m}$ and between $501 \mathrm{~m}$ to $1500 \mathrm{~m}$ of Minhocão. The survey was conducted between December/2017 until March/2019 with an electronic questionnaire self-responded. We conducted bivariate analysis and Poisson regression to examine possible differences in LTPA according to the proximity of residences and use of Minhocão. The analysis used post-stratification weights. A total of 12,030 telephone numbers of people were drawn $(\leq 500 \mathrm{~m}=6,942$; and $>500 \mathrm{~m}$ to $\leq 1500 \mathrm{~m}=5,088)$. The final sample analyzed were of 235 residents who returned the questionnaires. There was a higher prevalence of individuals engaging in at least 150 minutes per week of LTPA among users than non-users (Prevalence Ratio=2.23, IC95\%1.72-2.90). People who used the park had higher prevalence of all types of LTPA than non-users. The results can serve to inform government decision-making on the future of Minhocão.
\end{abstract}

Keywords: Public open spaces; Open streets; Built environment; Leisure-time physical activity; Epidemiology

\section{Introduction}

Previous studies have shown that engagement in leisure-time physical activity (LTPA) can attenuate a variety of chronic diseases, decrease mortality, improve quality of life and life satisfaction, and increase life expectancy [1-3]. However, the systematic review showed that several variables are associated with LTPA, including individual and contextual factors [4]. Because of this, according to Sallis et al. [5], the most promising interventions for making individuals more active should be based on an ecological model 
approach. This model includes the built environment and facilities for LTPA, which should be available near residences of people.

From a public health perspective to promote LTPA, the public open spaces such as parks, pocket parks or squares, and bike paths are promising venues for engagement in these activities [6,7]. Studies show that a variety of factors can influence the use of public open spaces [8-11]. The quantity and quality of these spaces, their proximity of residences, and accessibility are some factors that are associated with usage for LTPA [8-11]. In addition to the public open spaces, the literature has reported other environmental interventions to promote LTPA like the open streets, which are avenues or streets that are closed temporarily for cars and open for people on weekends [12-14]. These interventions have been referred to in the literature using different terminology according to their objectives, such as "Recreational Bike Paths", "Open Streets", "Play Streets", "Leisure Cycling Routes", and "Leisure Places" [15]. These can consist of public open spaces for recreation, to provide community activities (e.g., LTPA classes), and to promote sustainable, efficient means of transport (e.g., cycling) [16].

The study by Sarmiento et al. [16] provided a summary of the available information on the open streets as a public health policy in the Americas and the Caribbean drawing on different databases. The authors identified a total of 38 programs. The most interventions were conducted in Colombia, United States, Peru, and Mexico. In addition, the authors identified some cities where initiatives entailing the closure of streets for LTPA have been implemented, that included São Paulo, in Brazil. The problem is the lack of studies evaluating the effectiveness of these interventions to verify relationships with physical activity in adults living in low- and middle-income countries.

The "President João Goulart Elevated Avenue", currently denominated "Minhocão" or "big earthworm" in English because of its shape in its $3.4 \mathrm{~km}$ long, was listed in Sarmiento et al. study [16] like an open street. This elevated avenue was inaugurated in 1971 only to ease traffic congestion for motor-vehicle traffic car $[17,18]$. However, this facility started to cause many problems for local residents like excess noise, dirt and air pollution [17]. Because this, São Paulo City Hall authorities have closed this elevated avenue for the motor-vehicle traffic initially at nights and later also on weekends an effort to reduce these problems [18]. Since this initiative was taken, the local population has been using voluntarily the elevated avenue for different LTPA, such as walking, running, and biking at nighttime and weekends. In 2018, the municipal councilors of São Paulo City approved the law of "Minhocão Park" [19], where the project provided the discussion for gradual phasing out of use of the elevated avenue by motor vehicles. The project had been included in the New Master Plan of São Paulo city since 2014 [20]. However, the discussion also includes the possible demolition of the elevated avenue and in 2021 the law of "Minhocão Park" was annulated.

In this case, it is important to verify possible contributions of this facility for LTPA for people living near of this elevated avenue. The rationale behind this study is underpinned by scientific and policy evidence. Firstly, a study conducted by Florindo et al. [7] showed that adults who lived in São Paulo city, Brazil, between 2014 and 2015 and that had access to two or more public open spaces (such as parks, squares or bike paths) within a 500-meter radius from their homes had significantly more likelihood to engage in leisure-time walking compared to those without these spaces available in their neighborhood. The study conducted with adults from Curitiba, south in Brazil, showed that users of parks at least once a week had a higher prevalence of leisure-time walking than nonusers [21]. However, there are few studies that evaluated the contributions of open streets 
like Minhocão for LTPA in low- and medium-income countries. Lastly, from a political standpoint, discussions on the future of the elevated avenue (demolition or creation of a park) gained impetus in 2021 with the review of the New Master Plan for São Paulo approved in 2014 [20]. Thus, the results of the present study can serve to foster this discussion. Therefore, the objective of the present study was to examine if the prevalence of LTPA among individuals living in the surrounding of Minhocão is different according to proximity of their residences and according to the usage of the facility.

\section{Materials and Methods}

\subsection{Study site}

São Paulo is the most populous city in Brazil and the eighth in the world, with an estimated population for 2021 of 12,396,372 million inhabitants living in 1,521,110 km² [22], a concentration of $11 \%$ of the Gross Domestic Product of Brazil, currently has 651.9 $\mathrm{km}$ of cycle paths and cycle lanes [23], $101.1 \mathrm{~km}$ of subway lines with 89 stations [24] and 106 parks.

The Minhocão is an elevated highway (Figure 1a) with $3.4 \mathrm{~km}$, five meters above the ground, dual roadway, with four lanes in each direction separated by a central concrete barrier wall. The elevated avenue has nine points of access. Some of its sections are only five meters away of the facades of buildings on its sides [25]. The elevated highway is closed for motor-vehicle traffic and open for recreational activities, including physical activity from Monday to Thursday, from $8 \mathrm{pm}$ to $7 \mathrm{am}$ and, on weekends $8 \mathrm{pm}$ on Friday until 6 am on Monday. 
Figure 1. Location of Minhocão in São Paulo city, Brazil (1a); and census tracts of residents randomly selected according to buffer zones with different radiuses from entrances to Minhocão (1b).

Figure 1a

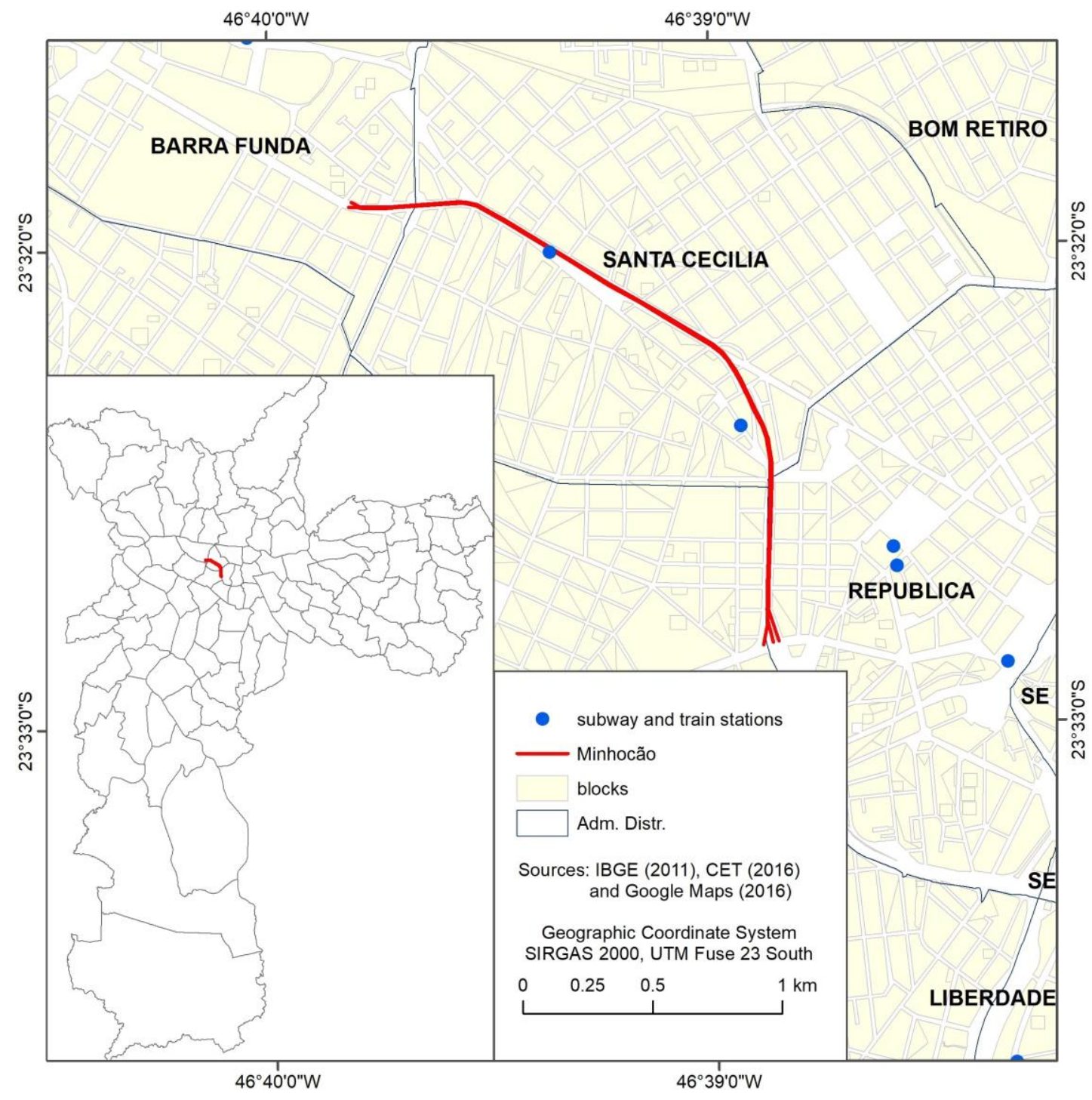


Figure 1b.

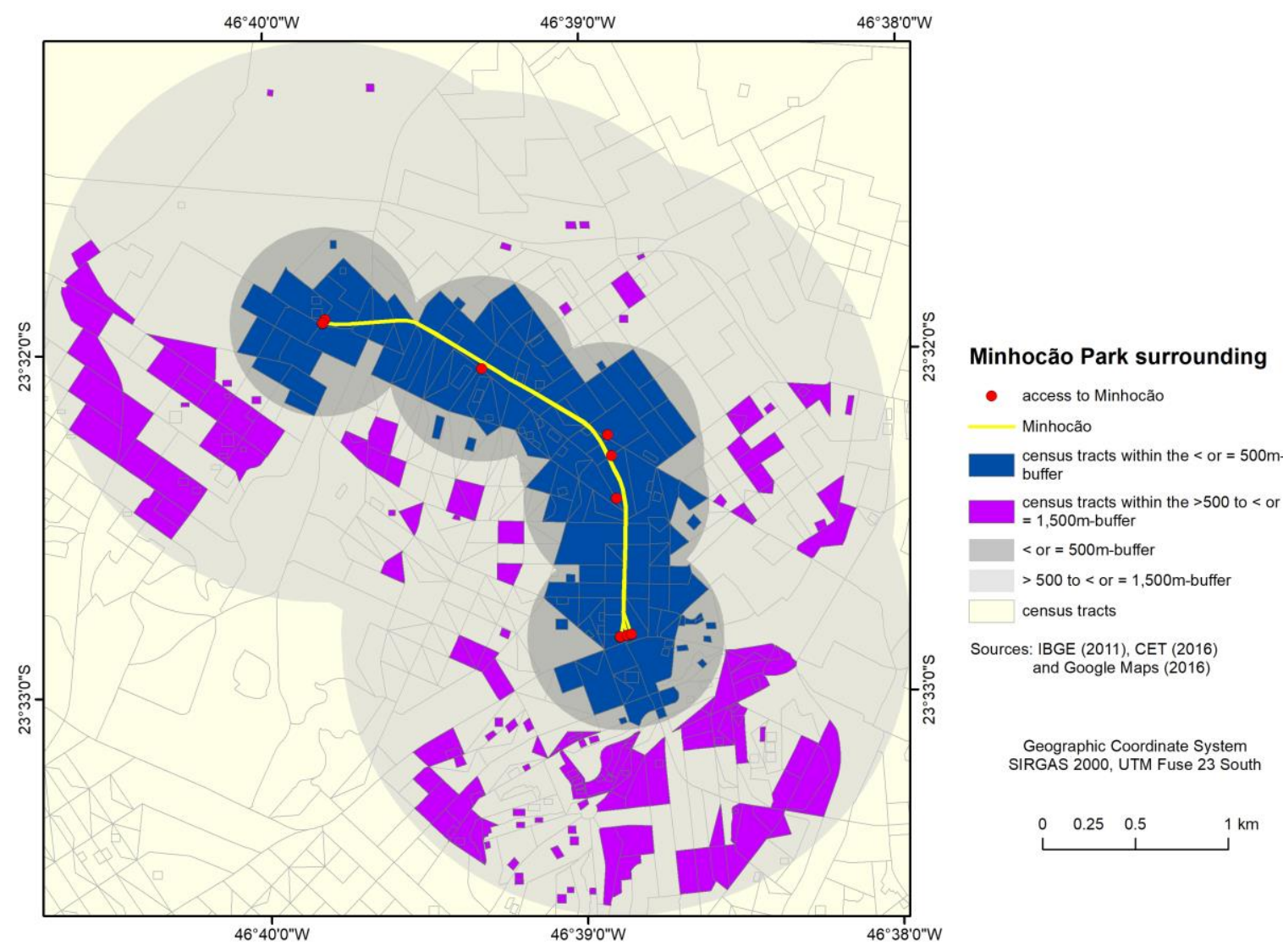

2.2. Study design and sample

We conducted a cross-sectional telephone and email survey. The target population comprised individuals aged $\geq 18$ years who lived in households until within 1,500 meters of the main access of Minhocão (Figure 1b).

The sample size was calculated considering a confidence level of $95 \%$, test power of $80 \%$, the proportion of people exposed positives of $45 \%$ (people who lived until 500 meters of a facility for bicycle and walking and practiced $\geq 150$ minutes per week of LTPA), and non-exposed positives of 34\% (people who lived between 501 meters until 1500 meters of a facility for bicycle and walking, and practiced $<150$ minutes per week of LTPA). The results were obtained in a study conducted by Pazin et al. [26]. The needed sample size would be 616 adults in total ( 308 adults living until 500 meters of the main access, and 308 adults living between 501 meters to 1,500 meters of the main access).

Households located within 1,500 meters of the elevated highway access points were randomly selected. Using Arc Map version 10.3 (Redlands, CA, USA), we identified the census tracts lying fully within one of the two buffer zones of interest: $\leq 500$ meters (Group 1 ), and $>500$ to $\leq 1,500$ meters radius (Group 2) from a highway access (Figure 1b). Census tracts were based on the 2010 national census conducted by the Brazilian Institute of Geography and Statistics. Buffer sizes were based on the results from the study by Pazin et al. [26]. We identified 164 tracts in Group 1 and other 164 tracts in Group 2.

We conducted cluster sampling with a 2-stage selection process and probability proportional to the cluster size. The census tracts were the primary sampling units. Fifty-eight tracts were randomly selected in Group 1 and 37 tracts in Group 2. The second sampling 
units were the addresses (street name, number, and postal code of each randomized tract), with a total of 15 addresses randomly selected per tract. After random selection of addresses, we randomly selected home telephone numbers. The list of telephone numbers associated to a given address was retrieved from the websites of the telephone service operators. All available telephone numbers associated with the selected addresses were collected. For example, if an address corresponded to an apartment building, all available telephone numbers of all apartments were selected. A total of 12,030 telephone numbers of individuals living in the vicinity of Minhocão $(\leq 500 \mathrm{~m}=6,942$; and $>500 \mathrm{~m}$ to $\leq 1500 \mathrm{~m}=$ $5,088)$ were randomly selected.

\subsection{Telephone call to sampled participants}

Undergraduate students from the Physical Activity Epidemiology Group at University of São Paulo were trained for a total of 15 hours on conducting telephone calls to the numbers of the randomly selected households. The students were given a password-protected spreadsheet containing all the randomly selected telephone numbers. In the event of three unsuccessful attempts to the same number at different times and on different days, no further calls were made to the number. In the event of successful calls, interviewers explained the objectives and importance of the survey and invited all adults ( $\geq 18$ years of age) members of the household to take part in the study. All individuals who agreed to participate were asked to provide an e-mail where the electronic survey questionnaire could be sent to. Follow-up letters and email messages were sent to survey participants to stimulate response rate. A mean of 1.3 call was conducted per number, resulting in successful contact for 6,977 telephone numbers (58\%). We posted follow-up letters to 1,306 households with at least one person who agreed on taking part in the survey.

\subsection{Electronic survey questionnaire}

The survey was conducted between December 2017 and March 2019. The questionnaire comprised of open and multiple-choice questions divided into six blocks: 1 . Sociodemographic variables, self-rated health, and self-reported weight and height; 2 . Leisuretime PA; 3. Use of Minhocão for leisure-time PA; 4 . Personal and environmental barriers to use the Minhocão; 5 . Social support; 6 . Self-efficacy. For this paper, responses to blocks 1,2 and 3 were analyzed.

Leisure-time PA was evaluated by the long version of the International Physical Activity Questionnaire (IPAQ), which was validated in a sample of Brazilian adults for its applicability in electronic form [27] and via e-mail [28], demonstrating good validity, reproducibility and concordance in both studies. This version of the IPAQ was standardized to collect information on engagement in leisure-time PA during the past seven days in minutes per day and number of days per week spent on walking, moderate and vigorous. Participants were probed about whether they used the Minhocão for leisure-time PA (yes or no).

The questionnaire was developed on the free platform Google Forms, allowing form sharing via any communication media using an URL to the questionnaire and real-time storage of responses on the cloud in the form of spreadsheets, with no need for manual data entry.

\subsection{Data analyses}

Means, confidence intervals, and absolute (n) and relative frequencies (\%) were used to describe the data. The chi-square test was applied to explore associations between (a) 
usage of the Minhocão (yes or not) and (b) distance from the participants' households to the closest entrance to the elevated avenue ( $\leq 500 \mathrm{~m}$; and $>500 \mathrm{~m}$ to $\leq 1,500 \mathrm{~m}$ ) and leisuretime walking, moderate and vigorous physical activity. In cases where chi-square assumptions were not met (cells containing expected values $\geq 5$ ), then Fisher's exact test was employed.

For associations with $\mathrm{p}$-value $<0.05$ in the bivariate analyses, we used Poisson regression models to determine the direction and magnitude of association between different types of LTPA and distance to and usage of the Minhocão. Multivariate models were adjusted for sex, age e education. Prevalence ratio (PR) were calculated with $95 \%$ confidence intervals. The construction of post-stratification weights was used to correct the bias due to the low response rate of the survey. The weights were calculated using the rake method, the variables age and sex of the population from the 2010 Census were used as a reference population in the construction of the weights. All statistical analyses were performed in the Stata software version SE 16.1 (StataCorp, College Station, TX, USA), using post-stratification weights to adjust the sample distribution for the population according to age and sex using the survey module (svy) [29].

\subsection{Study ethics}

The study was approved by the Research Ethics Committee of the University of São Paulo School of Public Health (protocol number 58449816.4.0000.5421).

\section{Results}

Of the results of 6,977 telephone numbers of people that were contacted with successful, we received the return of 421 emails of people with interest to answer the questionnaire. For finally, a total of 242 questionnaires were completed. Six questionnaires were subsequently excluded for containing non-randomized addresses, while another questionnaire was not included because the respondent was under 18 years of age. A total of 235 residents living near the Minhocão were included in the analysis. Respondents were predominantly male (53.6\%), aged 18 to 29 years $(28.9 \%)$, with educated to the higher level (56.2\%), lived within 500 meters of park entrances $(66.8 \%)$, and only $36.0 \%$ used the facility for PA in leisure-time. Most of the sample reported walking and moderate physical activity in leisure time (Table1). 
Table 1. Social and demographic characteristics, usage of the facility, and leisure-time physical activity of respondents that residing until 1,500 meters from the main access of Minhocão, São Paulo city, São Paulo State, Brazil, 2017-2019.

\begin{tabular}{rrrr}
\hline Variables & $\mathbf{\%} *$ & $\mathbf{( 9 5 \% \mathbf { C I } )}$ \\
\hline Sex & & \\
Female & 46.4 & $(39.4-53.6)$ \\
Male & 53.6 & $(46.4-60.6)$ \\
& & & \\
Age group (years) & & \\
$18-29$ & 28.9 & $(22.1-36.8)$ \\
$30-39$ & 21.5 & $(16.2-27.9)$ \\
$40-49$ & 16.3 & $(11.7-22.2)$ \\
$50-59$ & 14.2 & $(10.9-18.3)$ \\
$\geq 60$ & 19.1 & $(14.6-24.8)$
\end{tabular}

\section{Education}

Until complete high school $15.1 \quad(10.4-21.4)$

Incomplete or complete graduate $56.2(49.0-63.2)$

Incomplete or complete postgraduate $28.7(22.8-35.4)$

Distance of residence from main access Minhocão

$$
\begin{array}{rrr}
\leq 500 \text { meters } & 66.8 & (59.8-73.3) \\
>500 \text { to } \leq 1500 \text { meters } & 33.2 & (26.8-40.2)
\end{array}
$$

\section{Use of Minhocão for LTPA}

$$
\begin{array}{lll}
\text { No } & 64.0 & (56.6-70.9) \\
\text { Yes } & 36.0 & (29.1-43.4)
\end{array}
$$

\section{Leisure-time walking}

$$
\begin{array}{lll}
\text { No } & 42.1 & (35.3-49.3) \\
\text { Yes } & 57.9 & (50.7-64.7)
\end{array}
$$

Moderate physical activity in leisure time

$$
\begin{array}{lll}
\text { No } & 43.7 & (36.8-50.9) \\
\text { Yes } & 56.3 & (49.1-63.2)
\end{array}
$$

Vigorous physical activity in leisure time

$$
\begin{array}{lll}
\text { No } & 66.8 & (59.4-73.5) \\
\text { Yes } & 33.2 & (26.6-40.6)
\end{array}
$$

Total LTPA in the week**

$<150$ minutes $45.3 \quad(38.2-52.5)$ 
$\geq 150$ minutes $54.7 \quad(47.5-61.7)$

Notes: *post-stratification weight by age and sex; ${ }^{* *}$ Leisure-time physical activity (LTPA) including walking, moderate or vigorous; Abbreviation: CI: confidence interval

The LTPA not was associated with the proximity to the nearest of the access of Minhocão, according to people's home address (Table 2).

Table 2. Association of leisure-time physical activity among residents living in the surroundings of Minhocão according to distance of the residence address in São Paulo city, São Paulo state, Brazil, 2017-2019.

\begin{tabular}{|c|c|c|c|c|c|}
\hline \multirow[t]{2}{*}{ LTPA in past week } & \multicolumn{2}{|c|}{$\leq 500$ meters } & \multicolumn{2}{|c|}{$\begin{array}{c}501 \text { to } \leq 1500 \mathrm{me}- \\
\text { ters }\end{array}$} & \multirow[b]{2}{*}{$p^{* *}$} \\
\hline & $\% *$ & $(95 \% \mathrm{CI})$ & $\% *$ & $(95 \% \mathrm{CI})$ & \\
\hline \multicolumn{6}{|l|}{ Walking } \\
\hline No & 40.3 & $(32.1-49.1)$ & 45.8 & $(33.9-58.2)$ & 0.470 \\
\hline Yes & 59.7 & $(51.0-67.9)$ & 54.2 & $(41.8-66.1)$ & \\
\hline \multicolumn{6}{|l|}{ Moderate } \\
\hline No & 43.1 & $(34.7-51.9)$ & 45.0 & $(33.2-57.4)$ & 0.803 \\
\hline Yes & 56.9 & $(48.1-65.3)$ & 55.0 & $(42.6-66.8)$ & \\
\hline \multicolumn{6}{|l|}{ Vigorous } \\
\hline No & 64.3 & $(55.1-72.5)$ & 71.8 & $(58.8-81.9)$ & 0.327 \\
\hline Yes & 35.7 & $(27.5-44.9)$ & 28.2 & $(18.1-41.2)$ & \\
\hline \multicolumn{6}{|l|}{ Total LTPA*** } \\
\hline$<150$ minutes per week & 44.8 & $(36.3-53.6)$ & 46.3 & $(34.4-58.7)$ & 0.844 \\
\hline$\geq 150$ minutes per week & 55.2 & $(46.4-63.7)$ & 53.7 & $(41.3-65.6)$ & \\
\hline
\end{tabular}

Notes: ${ }^{*}$ post-stratification weight by age and sex; ${ }^{* *} \mathrm{p}$-values for Pearson's chisquared test; ${ }^{* * *}$ Leisure-time physical activity (LTPA) including walking, moderate or vigorous; Abbreviation: CI: confidence interval

Minhocão usage was positively associated with walking, moderate, and vigorous LTPA (Table 3).

Table 3. Association between use of Minhocão and leisure-time PA among adults living until 1,500m from main access in São Paulo city, São Paulo state, Brazil, 2017-2019.

\section{Use of Minhocão for leisure-time PA}

LTPA in past week

\begin{tabular}{|c|c|c|c|c|}
\hline & No & & Yes & \\
\hline$\% *$ & $(95 \% \mathrm{CI})$ & $\%$ * & $(95 \% \mathrm{CI})$ & $p^{* *}$ \\
\hline
\end{tabular}




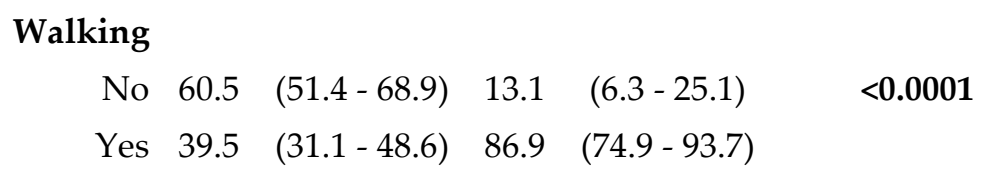

\section{Moderate}

$\begin{array}{llllll}\text { No } & 61.3 \quad(52.2-69.7) & 13.3 \quad(6.8-24.4) \quad<0.0001\end{array}$

Vigorous

$\begin{array}{llllll}\text { No } & 76.6 & (67.6-83.8) & 44.1 & (31.9-57.0) & <0.0001 \\ \text { Yes } & 23.4 & (16.2-32.4) & 55.9 & (43.0-68.1)\end{array}$

Total LTPA

$<150$ minutes per week $63.1 \quad(53.9-71.4) \quad 11.7 \quad(5.8-21.9) \quad<0.0001$

$\begin{array}{lllll}\geq 150 \text { minutes per week } \quad 36.9 & (28.6-46.1) & 88.3 \quad(78.1-94.2)\end{array}$

Notes: *post-stratification weight by age and sex; ${ }^{* *}$ p-values for Pearson's chi-squared test; Boldface indicates significant associations; ${ }^{* *}$ Leisure-time physical activity (LTPA) including walking, moderate or vigorous Abbreviation: CI: confidence interval

There was a higher prevalence of individuals engaging in leisure-time walking, moderate, vigorous and total LTPA among Minhocão users than non-users, independently of sex, age, and education (Table 4). 
Table 4. Prevalence ratios for leisure-time PA according to use of Minhocão among adults living in until 1,500m from main access, São Paulo city, São Paulo State, Brazil, 2017-2019.

\begin{tabular}{|c|c|c|c|}
\hline \multicolumn{2}{|l|}{ Use of Minhocão for LTPA } & $\begin{array}{c}\text { Model } 1 \text { PR }^{*} \\
(95 \% \mathrm{CI})\end{array}$ & $\begin{array}{c}\text { Model } 2 \text { PR } \\
(95 \% \mathrm{CI})^{* *}\end{array}$ \\
\hline \multicolumn{4}{|l|}{ Walking } \\
\hline & No & 1 & 1 \\
\hline & Yes & $2.20(1.72-2.82)$ & $2.10(1.63-2.71)$ \\
\hline \multicolumn{4}{|l|}{ Moderate } \\
\hline & No & 1 & 1 \\
\hline & Yes & $2.24(1.75-2.87)$ & $2.17(1.69-2.80)$ \\
\hline \multicolumn{4}{|l|}{ Vigorous } \\
\hline & No & 1 & 1 \\
\hline & Yes & $2.39(1.58-3.63)$ & $2.08(1.36-3.19)$ \\
\hline \multicolumn{4}{|l|}{ Total LTPA ${ }^{* * *}$} \\
\hline \multicolumn{2}{|c|}{$<150$ minutes per week } & 1 & 1 \\
\hline \multicolumn{2}{|c|}{$\geq 150$ minutes per week } & $2.39(1.86-3.09)$ & $2.23(1.72-2.90)$ \\
\hline
\end{tabular}

Notes: * post-stratification weight by age and sex; ${ }^{* *}$ adjusted for sex, age, education; ${ }^{* * *}$ Leisuretime physical activity (LTPA) including walking, moderate or vigorous; Boldface indicates significant associations; Abbreviation: PR: Prevalence ratio; CI: confidence interval; PA (physical activity).

\section{Discussion}

This study examined the relationship between the proximity of residences of people and the usage of Minhocão with LTPA, which is an elevated avenue that is transformed into an open street for people during the nights and on the weekends. This paper found that Minhocão users engaged in more LTPA than non-users. People that used the facility had higher prevalence of all types of LTPA investigated and of people achieving the recommended levels of physical activity only in the leisure domain. However, the proximity of the nearest access of the elevated avenue according to people's home address was not associated with LTPA.

Studies have shown that facilities and open streets like Minhocão are important to promote LTPA [8,15,16,30-32], particularly in megalopolis like São Paulo, where environmental inequities are a big problem [20].

The results of this paper were like the cross-sectional study of 749 intentionally selected adults in four parks $(n=303)$ and four squares $(n=446)$ in Curitiba city, Southeast Brazil, which showed that users of parks at least once a week had a higher prevalence of leisure-time walking (Prevalence Ratio $=1.30 ; 95 \%$ CI 1.03-1.64) than non-users. [21].

However, this paper did not find a statistical association between the proximity of nearest access of Minhocão of people's residences (distances $\leq 500$ meters) and LTPA, 
which was different from the results of another research [7]. The study conducted by Florindo et al. [7] with a sample of 3,145 adults of Sao Paulo city, Brazil, showed that individuals who had access to two or more public open spaces (such as parks, squares, or bike paths) within a 500-meter radius of their homes had a significantly greater likelihood of engaging in any level of leisure-time walking $(\mathrm{OR}=1.65$; 95\%CI $1.09-2.55)$ compared with individuals without access to these spaces near their homes. A cross-sectional study carried out in Hong Kong, China, between 2007 and 2008 reported similar results, showing that the presence of parks within a 400-meter radius of residences of older adults was associated with engagement in leisure-time walking ( $\mathrm{OR}=1.0395 \% \mathrm{CI}=1.02-1.05)$ [33]. Probably our analyses suffered with the small sample size, which might not be sufficient to answer this question. This type of sample selection conducted in two phases (telephone and email) was very difficult, and the response rate was low. Another possible issue is the characteristics of Minhocão, which is an open street and not a traditional park. The Minhocão is open for people during the night and the weekend days. Questions about safety also are important, because the region where the elevated avenue is has a high index of criminality in thefts and robberies [34].

The present study had two several limitations. The first was that the online surveys were only completed by respondents who had a landline, an email address and internet access via computer, smartphone or tablet. With advances in technology, many telephone users rely on mobile phones and no longer have a landline. However, according to the National Telecommunications Agency, São Paulo State had 89.3\% coverage of households with landlines in 2019 [35] and, according to Bernal et al. [36], the use of domestic landlines is recommended for carrying out epidemiological surveys in areas whose coverage exceeds $70 \%$. The use of post-stratification wieghts by age and sex according to the Population Census helped decrease this limitation.

Another aspect to note was the low response rate and the self-selection bias. The sample selection procedure conducted in two phases (by telephone and by email) was very difficult. Individuals may have declined to answer the questionnaire because they had limited accessibility to the internet or familiarity with computers, smartphones, emails, and the internet, particularly among low socioeconomic level families and older people. In addition, it is unclear whether the high refusal rates reflect resistance to implementing the park among local residents or whether most respondents were in favor of creating the park. This sample size might have affected the power of our analysis examining the relationship between the proximity of residences to the nearest park entrance and LTPA. But the use of post-stratification weights in the analysis decreases the selfselection bias.

Despite these limitations, we believe that the first results that showed that the users of Minhocão are more physically active in the LTPA than non-users are important to support this open street to physical activity promotion in Downtown in São Paulo city. The results are relevant to help the gap about evaluation studies of open streets for physical activity promotion in low- and middle-income countries. For example, in Colombia, a free community program called "Ciclovía Recreativa" makes available $121 \mathrm{~km}$ of temporarily pedestrianized streets to the public for LTPA on pre-defined days and hours [16]. A crosssectional study found that $59.5 \%$ of program users attained recommended levels of physical activity only in the leisure domain [38].

For finally, actions and programs coordinate by City Hall authorities that exploit the built environment creating open streets for people during the weekends, as it is done for Minhocão, are important population-level interventions with the potential to reach a large 
number of people, contributing to the World Health Organization Global Action Plan for physical activity promotion [39]. These efforts are important to continue with good results in public health like an increase of $7.8 \%$ in LTPA populations levels among adults residing in São Paulo between 2006 and 2016 [40]. Such initiatives are especially relevant amid the COVID-19 pandemic, where recent Brazilian epidemiological studies have revealed a decline in LTPA among adults [41].

\section{Conclusion}

This study showed that the users of Minhocão are more physically active in their leisure time than non-users. However, the proximity between people's residences and the nearest access to the elevated avenue was not statically associated with LTPA. We believe that these results can inform new discussions about the elevated avenue and inform the government and population during decision-making about the future of this open street.

Author Contributions: E. Q. R. and A. A. F. conceptualized the idea. E. Q. R. analyzed the data and led the writing. L. V. B. geocoded the residential address and took the measures in GIS. R. T. I. B. calculated and randomly selected the sample and made the sample weights. R. T. I. B., L. M. T. G., R. C. F. and A. A. F. helped with statistical analysis. E. H. C. R., D. R. A., J. P. A. S. B. and A. P. O. B. N. helped and supported the data collection. All authors contributed significantly to critical revision and drafting of the article.

Funding: E. Q. R. received a scholarship from Coordination for the Improvement of Higher Education Personnel (CAPES) (process number: 1505656 / 03/2015 - 02/2019).

Institutional Review Board Statement: The study was conducted according to the guidelines of the Declaration of Helsinki and approved by the Research Ethics Committee of the University of São Paulo School of Public Health (protocol number 58449816.4.0000.5421).

Informed Consent Statement: Informed consent was obtained from all subjects involved in the study.

Conflicts of Interest: All authors declare no conflict of interest.

\section{References}

1. Arem H, Moore SC, Patel A, Hartge P, Berrington De Gonzalez A, Visvanathan K, et al. Leisure time physical activity and mortality: A detailed pooled analysis of the dose-response relationship. JAMA Intern Med. 2015;175:959-67.

2. Mok A, Khaw K-T, Luben R, Wareham N, Brage S. Physical activity trajectories and mortality: population based cohort study. BMJ [Internet]. 2019 [citado 10 de julho de 2019];365:12323. Recuperado de: http://dx.doi.org/10.1136/bmj.12323

3. Barradas SC, Barboza CF, Sarmiento OL. Differences between leisure-time physical activity, health-related quality of life and life satisfaction: Al Ritmo de las Comunidades, a natural experiment from Colombia. Glob Health Promot [Internet]. SAGE PublicationsSage UK: London, England; 2019 [citado 22 de janeiro de 2019];26:5-14. Recuperado de: http://journals.sagepub.com/doi/10.1177/1757975917703303

4. Bauman AE, Reis RS, Sallis JF, Wells JC, Loos RJF, Martin BW, et al. Correlates of physical activity: Why are some people physically active and others not? Lancet [Internet]. Elsevier Ltd; 2012;380:258-71. Recuperado de: https://linkinghub.elsevier.com/retrieve/pii/S0140673612607351

5. Sallis JF, Cervero RB, Ascher W, Henderson KA, Kraft MK, Kerr J. an Ecological Approach To Creating Active Living Communities. Annu Rev Public Health [Internet]. 2006 [citado 6 de dezembro de 2018];27:297-322. Recuperado de: 
http://www.annualreviews.org/doi/10.1146/annurev.publhealth.27.021405.102100

6. Bedimo-Rung AL, Mowen AJ, Cohen DA. The significance of parks to physical activity and public health: A conceptual model. Am J Prev Med [Internet]. Elsevier; 2005 [citado 11 de dezembro de 2018];28:159-68. Recuperado de: https://www.sciencedirect.com/science/article/pii/S0749379704003046\#fig1

7. Florindo A, Barrozo L, Cabral-Miranda W, Rodrigues E, Turrell G, Goldbaum M, et al. Public Open Spaces and Leisure-Time Walking in Brazilian Adults. Int J Environ Res Public Health [Internet]. 2017;14:553. Recuperado de: http://www.mdpi.com/1660$4601 / 14 / 6 / 553$

8. Fermino R, Reis R. Variáveis individuais, ambientais e sociais associadas com o uso de espaços públicos abertos para a prática de atividade física: uma revisão sistemática. Rev Bras Atividade Física Saúde [Internet]. 2014;18:523-35. Recuperado de: http://periodicos.ufpel.edu.br/ojs2/index.php/RBAFS/article/view/3286

9. Kaczynski AT, Henderson KA. Environmental correlates of physical activity: A review of evidence about parks and recreation. Leis Sci. Taylor \& Francis; 2007;29:315-54.

10. McCormack GR, Shiell A. In search of causality: A systematic review of the relationship between the built environment and physical activity among adults. Int J Behav Nutr Phys Act [Internet]. 2011;8:125. Recuperado de: http://ijbnpa.biomedcentral.com/articles/10.1186/1479-5868-8-125

11. Hunter RF, Christian H, Veitch J, Astell-Burt T, Hipp JA, Schipperijn J. The impact of interventions to promote physical activity in urban green space: A systematic review and recommendations for future research. Soc Sci Med [Internet]. Elsevier Ltd; 2015 [citado 24 de janeiro de 2019];124:246-56. Recuperado de: https://www.sciencedirect.com/science/article/pii/S0277953614007837?via\%3Dihub

12. Kuhlberg JA, Hipp JA, Eyler A, Chang G. Open Streets Initiatives in the United States: Closed to Traffic, Open to Physical Activity. J Phys Act Heal [Internet]. 2015;11:1468-74. Recuperado de: http://journals.humankinetics.com/doi/10.1123/jpah.2012-0376

13. Hipp JA, Bird A, van Bakergem M, Yarnall E. Moving targets: Promoting physical activity in public spaces via open streets in the US. Prev Med (Baltim) [Internet]. Elsevier Inc.; 2017;103:S15-20. Recuperado de: http://dx.doi.org/10.1016/j.ypmed.2016.10.014

14. Umstattd Meyer MR, Bridges CN, Schmid TL, Hecht AA, Pollack Porter KM. Systematic review of how Play Streets impact opportunities for active play, physical activity, neighborhoods, and communities. BMC Public Health [Internet]. BMC Public Health; 2019;19:1-16. Recuperado de: https://bmcpublichealth.biomedcentral.com/articles/10.1186/s12889-019-66094?utm_source=researcher_app\&utm_medium=referral\&utm_campaign=MKEF_USG_Researcher_inbound

15. Sá T, Garcia L, Andrade D. Reflexões sobre os benefícios da integração dos programas Ruas de Lazer e Ciclofaixas de Lazer em São Paulo. Rev Bras Atividade Física Saúde [Internet]. 2017 [citado 25 de abril de 2019];22:5-12. Recuperado de: https://periodicos.ufpel.edu.br/ojs2/index.php/RBAFS/article/view/7767

16. Sarmiento OL, Torres A, Jacoby E, Pratt M, Schmid TL, Stierling G. The Ciclovía-Recreativa: A Mass-Recreational Program With Public Health Potential. J Phys Act Heal [Internet]. 2010;7:S163-80. Recuperado de: http://journals.humankinetics.com/doi/10.1123/jpah.7.s2.s163

17. Oliveira A de. O Elevado João Goulart - A história do Minhocão [Internet]. São Paulo foco. 2013 [citado 12 de fevereiro de 2019 ]. 
Recuperado de: http://www.saopauloinfoco.com.br/construcao-elevado-costa-e-silva/

18. Folha de São Paulo. Elevado fecha à noite desde 76 [Internet]. Folha São Paulo. 1995 [citado 27 de janeiro de 2019]. Recuperado de: https://www1.folha.uol.com.br/fsp/1995/12/13/cotidiano/33.html

19. Câmara Municipal de São Paulo. Prefeitura sanciona lei que cria o Parque Minhocão [Internet]. Câmara Munic. São Paulo. 2016 [citado 28 de janeiro de 2019]. Recuperado de: http://documentacao.saopaulo.sp.leg.br/cgibin/wxis.bin/iah/scripts/?IsisScript=iah.xis\&lang=pt\&format=detalhado.pft\&base=proje\&form=A\&nextAction=search\&indexSearch $=\% 5$ EnTw $\% 5$ ElTodos os campos\&exprSearch=P=PL222015

20. Prefeitura de São Paulo. Plano Diretor Estratégico do Município de São Paulo. 2014;

21. Fermino RC, Reis RS, Cassou AC. Fatores individuais e ambientais associados ao uso de parques e praças por adultos de CuritibaPR, Brasil. Rev Bras Cineantropometria e Desempenho Hum. 2012;14:377-89.

22. IBGE. Estimativas da população residente nos municípios brasileiros com data de referência em $1^{\circ}$ de julho de 2020 [Internet]. 2020 [citado 12 de devereiro 2020]. Recuperado de https://ftp.ibge.gov.br/Estimativas_de_Populacao/Estimativas_2020/estimativa_dou_2020.pdf

23. CET. CET - Companhia de Engenharia de Trafego - Bicicleta [Internet]. 2021 [citado 25 de outubro de 2021]. Recuperado de: http://www.cetsp.com.br/consultas/bicicleta/mapa-de-infraestrutura-cicloviaria.aspx

24. Companhia do Metropolitano de São Paulo. Metrô São Paulo | Quem somos - saiba sobre transporte metropolitano [Internet]. 2021 [citado 25 de outubro de 2021]. Recuperado de: http://www.metro.sp.gov.br/metro/institucional/quem-somos/index.aspx

25. Silva IOP da, Kalil Á, Amparo AGJ, Martins AP, Zemantaukas DS, Perez R, et al. Espaço urbano, fluxos e direitos: percursos no Elevado João Goulart (Minhocão). Alabastro [Internet]. 2017 [citado 13 de fevereiro de 2019];1:64-74. Recuperado de: http://revistaalabastro.fespsp.org.br/index.php/alabastro/article/viewFile/203/93

26. Pazin J, Garcia LMT, Florindo AA, Peres MA, Guimarães AC de A, Borgatto AF, et al. Effects of a new walking and cycling route on leisure-time physical activity of Brazilian adults: A longitudinal quasi-experiment. Heal Place. Elsevier; 2016;39:18-25.

27. Pires AAP, Pires Junior R, Oliveira RF de. Concordância entre os formatos impresso e eletrônico do IPAQ-L. Rev Bras Med do Esporte [Internet]. 2014 [citado 26 de julho de 2019];20:474-9. Recuperado de: http://dx.doi.org/10.1590/1517-86922014200602134

28. Alves V. Validade e aplicabilidade do questionário internacional de atividade física aplicado via e-mail em adultos [Internet]. Universidade Estadual Paulista, Instituto de Biociências de Rio Claro; 2013 [citado 26 de julho de 2019]. Recuperado de: https://repositorio.unesp.br/bitstream/handle/11449/87029/000713908.pdf;jsessionid=70B7A241BC441FF981CAA4C1411A0291?sequ ence $=1$

29. Winter N. SURVWGT: Stata module to create and manipulate survey weights. 2002;revised 11 Feb 2018.

30. Koohsari MJ, Mavoa S, Villianueva K, Sugiyama T, Badland H, Kaczynski AT, et al. Public open space, physical activity, urban design and public health: Concepts, methods and research agenda. Heal Place [Internet]. Elsevier; 2015;33:75-82. Recuperado de: http://dx.doi.org/10.1016/j.healthplace.2015.02.009

31. Sugiyama T, Neuhaus M, Cole R, Giles-Corti B, Owen N. Destination and route attributes associated with adults' walking: A 
review. Med Sci Sports Exerc. 2012;44:1275-86.

32. Sugiyama T, Cerin E, Owen N, Oyeyemi AL, Conway TL, Van Dyck D, et al. Perceived neighbourhood environmental attributes associated with adults' recreational walking: IPEN adult study in 12 countries. Health Place [Internet]. 2014;28:22-30. Recuperado de: https://linkinghub.elsevier.com/retrieve/pii/S1353829214000392

33. Cerin E, Lee K yiu, Barnett A, Sit CHP, Cheung M chin, Chan W man. Objectively-measured neighborhood environments and leisure-time physical activity in Chinese urban elders. Prev Med (Baltim). Elsevier Inc.; 2013;56:86-9.

34. Estadão. Criminalidade Bairro a Bairro [Internet]. Estadão. Recuperado de: https://infograficos.estadao.com.br/public/cidades/criminalidade-bairro-a-bairro/

35. ANATEL. Telefonia fixa soma 37,4 milhões de linhas em janeiro de 2019 [Internet]. Anatel. 2019 [citado 26 de março de 2019]. Recuperado de: http://www.anatel.gov.br/dados/index.php/acessos-telefonia-fixa

36. Bernal RTI, Malta DC, Araújo TS, Silva NN da. Inquérito por telefone: pesos de pós-estratificação para corrigir vícios de baixa cobertura em Rio Branco, AC. Rev Saude Publica [Internet]. 2013;47:316-25. Recuperado de: http://www.scielo.br/scielo.php?script=sci_arttext\&pid=S0034-89102013000200316\&lng=pt\&tlng=pt

37. Instituto de Pesquisa Datafolha. Elevado João Goulart - Eleições municipais. 2020;

38. Torres A, Sarmiento OL, Stauber C, Zarama R. The ciclovia and cicloruta programs: Promising interventions to promote physical activity and social capital in bogotá, Colombia. Am J Public Health [Internet]. 2013 [citado 22 de janeiro de 2019];103:e23-30. Recuperado de: http://www.ncbi.nlm.nih.gov/pubmed/23237179

39. WHO WHO. Global action plan on physical activity 2018-2030: more active people for a healthier world. Geneva; 2018; Recuperado de: www.who.int/lets-be-active/en/

40. Dias TG, Nunes APB de O, Santos C de O, Cruz M dos S da, Guerra PH, Bernal RTI, et al. Nível de atividade física no lazer em adultos paulistanos: uma análise de tendência de 2006 a 2016. Rev Bras Epidemiol [Internet]. Associação Brasileira de Saúde Coletiva; 2020 [citado 16 de setembro de 2021];23:e200099. Recuperado de: http://www.scielo.br/j/rbepid/a/tSBP8pVQ9Nzt9HZnKLPsJXp/?lang=pt

41. Silva DRP da, Werneck AO, Malta DC, Souza Júnior PRB de, Azevedo LO, Barros MB de A, et al. Changes in the prevalence of physical inactivity and sedentary behavior during COVID-19 pandemic: a survey with 39,693 Brazilian adults. Cad Saude Publica [Internet]. 2021;37. Recuperado de: http://www.scielo.br/scielo.php?script=sci_arttext\&pid=S0102-311X2021000300504\&tlng=en 